\title{
ANALISIS PREDIKSI KEBANGKRUTAN DENGAN MODEL ALTMAN DAN SPRINGATE PADA BANK BUMN PERIODE 2013 - 2015
}

\author{
Oleh \\ Endang Purwanti \\ STIE AMA Salatiga
}

\begin{abstract}
Abstrak
Kondisi perekonomian di Indonesia yang masih belum menentu mengakibatkan tingginya resiko suatu perusahaan untuk mengalami kesulitan keuangan atau bahkan kebangkrutan.Kesalahan prediksi terhadap kelangsungan operasional suatu perusahaan di masa yang akan datang dapat berakibat fatal yaitu kehilangan pendapatan atau investasi yang telah ditanamkan pada suatu perusahaan. Oleh karena itu, pentingnya suatu model prediksi kebangkrutan suatu perusahaan menjadi hal yang sangat dibutuhkan oleh berbagai pihak.

Tujuan penelitian ini adalah untuk mengetahui prediksi kebangkrutan Bank BUMN di BEI pada tahun 2013-2015.Sebagai satuan pengamatan ada 4 Bank $B U M N$, satuan analisis adalah laporan keuangan yang diolah dengan menggunakan analisis model Altman Z.Score dan Springate S-Score.

Hasil analisis menunjukan bahwa ke empat Bank BUMN (PT.Bank BNI Tbk,PT. Bank BRI Tbk,PT.Bank BTN Tbk,PT.Bank Mandiri Tbk.) tersebut diprediksi Bangkrut dengan model Altman dan model Springate S-Score, dengan hasil analisis tersebut maka keempat bank tersebut harus meningkatkan kinerja keuangannya dengan cara meningkatkan laba melalui peningkatan volume penjualan produk bank pada setiap tahunnya, yang harus diikuti dengan meningkatkan efisiensi penggunaan sumber daya yang dimiliki oeleh perusahaan dan efisiensi dalam biaya operasional, dengan memaksimalkan penggunaan asset, kewajiban dan modal yang dimiliki oleh perusahaan sehingga tidak ada sumber daya yang menganggur.
\end{abstract}

\section{Kata Kunci: Kebangkrutan,Model Altman, Model Springate}

\section{PENDAHULUAN}

Dalam dunia Modern sekarang ini, peranan perbankan dalam memajukan perekonomian suatu negara sangatlah besar. Secara sederhana bank diartikan sebagai lembaga keuangan yang kegiatan usahanya adalah menghimpun dana dari masyarakat dan menyalurkan kembali dana tersebut ke masyarakat, serta memberikan jasa-jasa bank lainnya.Kondisi perekonomian di Indonesia yang masih belum menentu mengakibatkan tingginya risiko suatu perusahaan untuk mengalami kesulitan keuangan atau bahkan kebangkrutan. Prediksi kesulitan ini salah satunya 
dikemukakan Edward Altman yang disebut dengan Altman Z-score. (Darsono dan Ashari, 2005).Sedangkan Springate (1978) model predisi kebangkrutan Springate dengan model prediksi kebangkrutan yang dikenal sebagai model Springate menggunakan empat rasio keuangan yaitu modal kerja,laba sebelum pajak, dan penjualan.(Rismawaty,2012).

Jika kinerja bank-bank BUMN bagus, maka kinerja industri perbankan keseluruhan juga akan bagus. Begitu juga sebaliknya. Bank-bank pemerintah rata-rata memiliki permodalan yang relatif lebih besar dibandingkan dengan bank-bank swasta. Namun demikian dalam dunia bisnis perbankan, keunggulan berkompetisi suatu bank tidak hanya dipengaruhi oleh besarnya permodalan suatu bank, tetapi banyak faktor yang memperngaruhinya. Suatu bank yang besar dengan modal yang besar belum tentu menjamin bank tersebut efisien, sehingga mampu menjadi bank yang tangguh.Pada penelitian ini, peneliti ingin melakukan analisis pada keempat bank BUMN tersebut dikarenakan bank pemerintah berposisi sebagai market leader dengan pangsa pasar yang besar, kinerja bank BUMN sangat mempengaruhi kinerja perbankan nasional sehingga kelak hasil penelitian ini dapat dijadikan pedoman bagi bank umum yang lain untuk menilai kinerja masing-masing perusahaan.

\section{Rumusan Masalah}

Berdasarkan pada latar belakang yang telah diuraikan, maka rumusan masalah dalam penelitian ini adalah : Bagaimana prediksi kebangkrutan pada bank BUMN Yang Terdaftar di BEI periode 2013-2015 dengan menggunakan metode Altman Z-score dan Springate ?

\section{Tujuan Penelitian Dan Manfaat Penelitian}

Tujuan penelitian ini untuk memprediksi Kebangkrutan Pada Bank BUMN yang terdaftar di BEI Periode 2013-2015 dengan model Altman Z Score dan Model Springate. Manfaat penelitian dapat digunakan sebagai acuan dan tambahan pengetahuan dalam memprediksi kebangkrutan perusahaan dengan menggunakan model Altman Z Score dan Model Springate

\section{PAPARAN TEORITIS}

Pengertian bank yang terdapat pada Pasal 1 Undang-Undang No. 10 tahun 1998 tentang Perubahan Undang-Undang No. 7 Tahun 1992 tentang Perbankan, bank adalah badan usaha yang menghimpun dana dari masyarakat dalam bentuk simpanan 
dan meyalurkannya kepada masyarakat dalam bentuk kredit dan/atau bentuk-bentuk lainnya dalam rangka meningkatkan taraf hidup rakyat banyak. Oleh karena Bank berfungsi sebagai perantara keuangan, maka dalam hal ini faktor Kepercayaan dari masyarakat merupakan faktor utama dalam menjalankan bisnis perbankan sehingga dalam mengelola bank harus dilakukan secara profesional, sehingga dapat memperoleh keuntungan yang terus menerus. Keuntungan atau laba yang diperoleh tercermin dari laporan keuangan. Hasil dari analisis laporan keuangan bisa dijadikan sebagai dasar memprediksi kebangkrutan suatu perusahaan jasa perbankan maupun perusahaan manufaktur.

\section{Laporan Keuangan}

Menurut Kasmir (2010), laporan keuangan adalah laporan yang menunjukkan kondisi keuangan perusahaan pada saat ini atau dalam suatu periode tertentu.Menurut Mamduh M. Hanafi (2005), laporan keuangan perusahaan merupakan salah satu sumber informasi yang penting di samping informasi lain seperti informasi industri, kondisi perekonomian, pangsa pasar perusahaan, kualitas menejemen, dan lainnya.

\section{a. Jenis Laporan Keuangan}

Menurut Mamduh M. Hanafi (2004), ada 3 jenis laporan keuangan yang sering digunakan, yaitu Neraca, Laporan Laba-Rugi, dan Laporan Aliran Kas.

\section{b. Analisis Laporan Keuangan}

Menurut Sofyan Syafri Harahap (2001), analisis laporan keuangan berarti menguraikan pos-pos laporan keuangan menjadi unit informasi yang lebih kecil dan melihat hubungannya yang bersifat signifikan atau yang mempunyai makna antara satu dengan yang lain baik antara data kuantitatif maupun data non kuantitatif dengan tujuan untuk mengetahui kondisi keuangan lebih dalam yang sangat penting dalam proses menghasilkan keputusan yang tepat.

Menurut Sunyoto (2013), teknik analisis laporan keuangan digunakan untuk menentukan dan mengukur hubungan antara pos-pos yang ada dalam laporan sehingga dapat diketahui perubahan-perubahan dari masing-masing pos tersebut bila diperbandingkan dengan laporan dari beberapa periode untuk satu perusahaan tertentu atau diperbandingkan dengan alat-alat pembanding 
lainnya.Menurut Mamduh M. Hanafi (2005), analisis terhadap laporan keuangan suatu perusahaan pada dasarnya karena ingin mengetahui tingkat profitabilitas (keuntungan) dan tingkat risiko atau tingkat kesehatan suatu perusahaan. Analisis rasio merupakan cara lain menyajikan informasi dari laporan keuangan.

Analisis ini disusun dengan menggabung-gabungkan angka-angka dalam dan antara neraca dan laporan rugi-laba. Ada lima kategori rasio keuangan yang sering digunakan, yaitu : Rasio Likuiditas,Rasio Aktivitas,Rasio Solvabilitas, Rasio Profitabilitas,Rasio Pasar.Sedangkan menurut Djarwanto (2004) mengemukakan rasio keuangan dikelompokan menjadi dua golongan yaitu:Berdasarkan sumber datanya,Berdasrkan tujuan penganalisisan dalam evaluasi suatu perusahaan berdasarkan laporan keuangan dikelompokan menjadi tiga kategori yaitu, rasio likuiditas untuk menguji kecukupandana, solvency perusahaan, rasio profitabilitas bertujuan untuk mengukur efisiensi aktivitas perusahaan dan kemampuan perusahaan untuk memperoleh keuntungan, rasio kepemilikan, berkaitan langsung atau tidak langsung dengan keuntungan dan likuiditas.

Menurut Prastowo,Dwi,dkk (2005) teknik analisis laporan keuangan ada beberapa macam :Laporan keuangan komparatif, dari laporan ini akan dapat diperoleh gambaran mengenai pergerakan dan kecenderungan serta memberikan petunjuk berharga dalam memprediksi peruahaan dimasa mendatang.Analisis Trend, analisis ini menggambarkan kecenderungan perubahan suatu pos laporan keuangan selama beberapa periode.Analisis Common-Size, menyatakan masing-masing pos dalam presentase.Analisis sumber dan penggunaan dana, dari analisis ini pengelola perusahaan akan memperoleh informasi mengenai sebab terjadinya surplus /defisit kas selama periode tertentu, sehingga dapat digunakan sebagai dasar pengambilan keputusan tentang kas.

\section{Kesulitan Keuangan}

Pengertian Kesulitan Keuangan menurut Mamduh M. Hanafi (2004), kesulitan usaha merupakan kondisi kontinum mulai dari kesulitan keuangan yang ringan (seperti masalah likuiditas) sampai pada kesulitan keuangan yang 
lebih serius, yaitu tidak solvable (hutang lebih besar dibandingkan dengan aset). Pada kondisi ini perusahaan praktis bisa dikatakan sudah bangkrut.Menurut Darsono dan Ashari (2005), kesulitan keuangan dapat diartikan sebagai ketidakmampuan perusahaan untuk membayar kewajiban keuangannya pada saat jatuh tempo yang menyebabkan kebangkrutan perusahaan. Menurut Darsono dan Ashari (2005), permasalahan dalam kesulitan keuangan bisa digolongkan ke dalam empat kategori, yaitu :Perusahaan yang mengalami masalah keuangan baik dalam jangka pendek maupun jangka panjang, sehingga mengalami kebangkrutan.

Perusahaan yang mengalami kesulitan keuangan jangka pendek namun bisa mengatasi, sehingga tidak menyebabkan kebangkrutan.Perusahaan yang tidak mengalami kesulitan keuangan jangka pendek tetapi mengalami kesulitan keuangan jangka panjang, sehingga ada kemungkinan mengalami kebangkrutan.Perusahaan yang tidak mengalami kesulitan keuangan dalam jang pendek yang berupa kesulitan likuiditas ataupun kesulitan keuangan jangka panjang.

\section{Penyebab Kesulitan Keuangan}

Menurut Mamduh M. Hanafi (2004), penyebab kesulitan keuangan dan kebangkrutan cukup bervariasi. Jenis industri itu sendiri mempengaruhi penyebab kegagalan usaha. Berikut faktor-faktor penyebab kegagalan bisnis pada umumya :Kekurangan pengalaman operasional, kekurangan pengalaman manajerial, pengalaman tidak seimbang antara keuangan, produksi, dan fungsi lainnya, manajemen yang tidak kompeten, Penyelewengan, Bencana, kealpaan. Sedangkan alasan lain kegagalan bisnis khususnya yang terjadi pada sektor usaha kecil adalah sebagai berikut :Struktur permodalan yang kurang, kekurangan modal untuk membeli barang modal dan peralatan, kekurangan modal untuk memanfaatkan barang persediaan yang dijual dengan potongan kuantitas, atau jenis potongan lainnya, menggunakan peralatan dan metode bisnis yang ketinggalan zaman, gagal menerapkan pengendalian persediaan,tidak dapat melakukan pengendalian kredit, kurang memadainya catatan akuntansi, ketiadaan perencanaan bisnis, ketidakmampuan mendeteksi dan memahami perubahan pasar, ketidakmampuan memahami perubahan 
kondisi ekonomi, tidak menyiapkan rencana untuk situasi darurat atau di luar dugaan, ketidakmampuan mengantisipasi dan merencanakan kebutuhan keuangan.Kualifikasi pribadi.

\section{Alternatif Perbaikan Kesulitan Keuangan}

Menurut Mamduh M. Hanafi (2004), beberapa alternatif perbaikan berdasarkan besar kecilnya permasalahan yang dihadapi oleh perusahaan. Tergantung tingkat keseriusan yang dialami oleh perusahaan, pemecahan bisa dilakukan secara informal dan formal. Berikut alternatif perbaikan kesulitan keuangan. Pemecahan Secara Informal, cara pemecahan secara informal yaitu :Perpanjangan (extension); dilakukan dengan memperpanjang jatuh tempo hutang-hutang. Komposisi (composition) dilakukan dengan mengurangi besarnya tagihan. Likuidasi Jika nilai likuidasi lebih besar dibandingkan nilai going concern, perusahaan bisa dilikuidasi secara informal. Pemecahan secara formal dilakukan apabila masalah sudah parah, kreditur dan pemasok lainnya ingin mempunyai jaminan keamanan dan keadilan. Pemecahan secara formal melibatkan pihak ketiga yaitu pengadilan.

\section{Kebangkrutan}

Kebangkrutan (bankruptcy) biasanya diartikan sebagai kegagalan perusahaan dalam menjalankan operasi perusahaan untuk menghasilkan laba. Kebangkrutan sebagai suatu kegagalan yang terjadi pada sebuah perusahaan didefinisikan dalam beberapa pengertian: Kegagalan ekonomi dalam kondisi ini perusahaan tidak dapat menutup biayanya sendiri, berarti tingkat laba lebih kecil dari biaya modal,atau nilai sekarang dari arus kas perusahaan lebih kecil dari kewajiban.Kegagalan keuangan mempunyai makna kesulitan dana baik dalam pengertian kas atau dalam pengertian modal kerja.Kebangkrutan merupakan kesulitan keuangan yang parah yang bisa digambarkan diantara dua titik ekstrem yaitu kesulitan likuiditas jangka pendek (yang paling ringan) sampai insovabel (yang paling parah).Sedangkan pengertian lain Kebangkrutan adalah suatu kondisi disaat perusahaan mengalami ketidak cukupan dana untuk menjalankan usahanya.

Ketidakmampuan untuk membaca sinyal-sinyal dalam kesulitan usaha akan mengakibatkan kerugian dalam investasi yang telah dilakukan. Untuk 
mengantisipasi hal tersebut, investor harus bisa mendeteksi kesulitan yang dialami oleh perusahaan. Salah satu sinyal untuk mendeteksi kemungkinan kesulitan keuangan adalah sinyal dari dalam perusahaan yang berupa indikator kesulitan keuangan. (Darsono dan Ashari, 2005:101)

Terdapat beberapa indikator yang bisa dijadikan panduan untuk menilai kesulitan keuangan yang akan diderita oleh beberapa perusahaan. Indikator pertama adalah informasi arus kas sekarang dan arus kas untuk periode mendatang. Informasi arus kas memberikan gambaran sumber-sumber dan penggunaan kas perusahaan. Sumber yang kedua adalah dari analisis posisi dan strategi perusahaan dibandingkan dengan pesaing. Informasi ini memberikan gambaran posisi perusahaan dalam persaingan bisnis yang merujuk pada kemampuan perusahaan dalam menjual produk atau jasanya untuk menghasilkan kas. Menurut Darsono dan Ashari (2005), berikut beberapa penyebab kebangkrutan baik berasal dari faktor internal maupun faktor eksternal.

\section{METODE PENELITIAN}

\section{Analisis Multivariate}

Model prediksi kebangkrutan multivariate yang cukup terkenal dan menjadi pioneer adalah model kebangkrutan yang dikembangkan oleh Altman (1969). Model tersebut menggunakan teknik statistik analisis diskriminan dan secara umum bisa dituliskan sebagai berikut ini : (Mamduh M. Hanafi, 2004:656)

\section{Analisis prediksi kebangkrutan Model Springate}

Springate membuat model prediksi Kebangkrutan pada tahun 1978. Dalam pembuatannya, Springate menggunakan metode yang sama dengan Altman (1968) yaitu Multiple Discriminant Analysis (MDA). Seperti Beaver (1966) dan Altman (1968), pada awalnya Springate (1978) mengumpulkan rasio-rasio keuangan populer yang bisa dipakai untuk memprediksi Kebangkrutan. (Rismawaty,2012).Sedangkan penelitian yang dilakukan oleh Gordon L.V Springate (1978) dalam Ni Made Evi Dwi Prihanthini dkk ( 2013) menghasilkan model prediksi kebangkrutan yang dibuat dengan mengikuti prosedur model Altman. Model prediksi kebangkrutan yang dikenal 
sebagai model Springate ini menggunakan 4 rasio keuangan. (Ni Made Evi Dwi Prihanthini,dkk, 2013 )

\section{Tipe Penelitian}

Sesuai dengan masalah dan tujuan yang dirumuskan, maka penelitian ini tergolong penelitian kuantitatif-deskriptif. Sedangkan menurut Arikunto (2010), penelitian deskriptif adalah penelitian yang dimaksudkan untuk menyelidiki keadaan, kondisi, situasi, peristiwa, kegiatan, dan lain-lain.

\section{Satuan Pengamatan dan Satuan Analisis}

Menurut W. Gulo (2005), satuan pengamatan adalah satuan tempat informasi diperoleh tentang satuan analisis. Satuan pengamatan dalam penelitian ini adalah bank BUMN yang go public yang terdaftar di BEI Sedangkan menurut Arikunto (2002), satuan analisis adalah satuan tertentu yang diperhitungkan sebagai subyek penelitian. Berdasarkan pengertian tersebut maka yang menjadi satuan analisis dalam penelitian ini adalah laporan keuangan bank BUMN yang go public yang terdaftar di BEI tahun 2013-2015.

\section{Definisi Konsep Dan Definisi Operasional}

Laporan Keuangan menurut Mamduh M. Hanafi (2004), laporan keuangan perusahaan merupakan salah satu sumber informasi yang penting di samping informasi lain seperti informasi industri, kondisi perekonomian, pangsa pasar perusahaan, kualitas menejemen, dan lainnya. Ada 3 jenis laporan keuangan yang sering digunakan, yaitu Neraca, Laporan Laba-Rugi, dan Laporan Aliran Kas. Analisis Laporan Keuangan menutut Danang Sunyoto (2013), teknik analisis laporan keuangan digunakan untuk menentukan dan mengukur hubungan antara pos-pos yang ada dalam laporan sehingga dapat diketahui perubahan-perubahan dari masing-masing pos tersebut bila diperbandingkan dengan laporan dari beberapa periode untuk satu perusahaan tertentu atau diperbandingkan dengan alat-alat pembanding lainnya. Kebangkrutan adalah ketidakmampuan mengantisipasi perkembangan global dengan memperkuat fundamental manajemen akan mengakibatkan pengecilan dalam volume usaha yang pada akhirnya mengakibatkan kebangkrutan perusahaan. (Darsono dan Ashari, 2005). 


\section{Definisi Operasional}

Dalam penelitian ini model Altman Z-scor yang menggunakan nilai buku karena hasil penelitian bisa sebagai acuan bagi bank lain yang belum go publik Dan Model Springate .

\section{Jenis dan Sumber Data}

Menurut Moh. Pabandu Tika (2006) data sekunder adalah data yang diperoleh dari kantor, buku (kepustakaan), atau pihak-pihak lain yang memberikan data yang erat kaitannya dengan onjek/tujuan penelitian.

\section{Metode Analisis Data}

Metode analisis data dalam penelitian ini adalah models Altman Z-score dan model Springate de ngan persamaan sebagai berikut :

$$
\mathrm{Zi}=\mathbf{0 , 7 1 7} \mathrm{X} 1+0,847 \mathrm{X} 2+\mathbf{3 , 1 0 7} \mathrm{X3}+\mathbf{0 , 4 2} \mathrm{X} 4+\mathbf{0 , 9 9 8} \mathrm{X5}
$$

\section{Model Springate}

$$
\mathrm{S}=1.03 \mathrm{~A}+3.07 \mathrm{~B}+0.66 \mathrm{C}+0.4 \mathrm{D}
$$

\section{Analisis Data}

\section{Analisis Model Altman Z-score}

Nilai Z-score untuk masing-masing Bank BUMN yang go public di BEI tahun 2013-2015 dapat dihitung dengan rumus model Altman Z-score sebagai berikut :

Tabel. 1

Rekapitulasi Hasil Perhitungan Z-score

Pada Bank BUMN yang Go Public di BEI Tahun 2013-2015

\begin{tabular}{|c|c|c|}
\hline & Nilai Z-score & Prediksi \\
\hline BNI & & \\
\hline 2013 & 0,373 & Bangkrut \\
\hline 2014 & 0,411 & Bangkrut \\
\hline 2015 & 0,365 & \\
\hline 2013 & 0,308 & Bangkrut \\
\hline 2014 & 0,357 & Bangkrut \\
\hline 2015 & 0,368 & Bangkrut \\
\hline BTIN & & Bangkrut \\
\hline 2013 & 0,198 & Bangkrut \\
\hline 2014 & 0,173 & \\
\hline 2015 & 0,184 & Bangkrut \\
\hline Iandiri & & Bangkrut \\
\hline 2013 & 0,371 & Bangkrut \\
\hline 2014 & 0,361 & 0,371 \\
\hline 2015 & &
\end{tabular}

Sumber: Data sekunder yang diolah, 2019 
Dari hasil rekapitulasi nilai Z-score bank BUMN yang go public di BEI tahun 2013-2015, dapat kita lihat bahwa selama tahun 2013-2015, keempat bank BUMN tersebut diprediksi mengalami kebangkrutan. Hal ini disebabkan karena keempat bank BUMN tersebut kurang mampu dalam menghasilkan laba yang ditahan dari total aset yang ada. Namun secara riil, keempat bank BUMN tersebut sampai saat ini masih bisa dibilang aman dari kebangkrutan. Hal ini dikarenakan, keunggulan dalam berkompetisi tidak hanya dipengaruhi oleh besarnya permodalan suatu bank saja, tetapi banyak faktor yang mempengaruhi. Loyalitas customer terhadap bank tersebut, manajemen perusahaan yang bagus baik manajemen terhadap sumber daya manusia ataupun manajemen terhadap operasionalnya.Oleh karena itu, keempat bank BUMN tersebut harus berhati-hati dalam menentukan kebijakan bagi perusahaan kedepannya. Dikarenakan jika manajemen salah dalam menentukan keputusan maka akan berakibat buruk yaitu kebangkrutan usaha. Peningkatan kinerja dapat dilakukan dengan cara meningkatkan volume penjualan produk bank pada setiap tahunnya, meningkatkan efisiensi penggunaan sumber daya yang dimiliki oleh perusahaan, misalnya dengan memaksimalkan penggunaan aset, kewajiban dan modal yang dimiliki oleh perusahaan, sehingga tidak ada sumber daya yang menganggur serta dapat memperoleh laba yang maksimal sesuai dengan yang diharapkan perusahaan.

\section{Analisis Model Springate}

Tabel. 2

Rekapitulasi Hasil Perhitungan S-score

Pada Bank BUMN yang Go Public di BEI Tahun 2013-2015

\begin{tabular}{|l|l|l|}
\hline BNI & \multicolumn{1}{|c|}{ S - score } & \multicolumn{1}{c|}{ Prediksi } \\
\hline 2013 & 0,339 & Bangkrut \\
\hline 2014 & 0,370 & Bangkrut \\
\hline 2015 & 0,321 & Bangkrut \\
\hline BRI & & \\
\hline 2013 & 0,317 & Bangkrut \\
\hline 2014 & 0,279 & Bangkrut \\
\hline 2015 & 0,281 & Bangkrut \\
\hline
\end{tabular}




\begin{tabular}{|l|l|l|}
\hline BTN & & \\
\hline 2013 & 0,150 & Bangkrut \\
\hline 2014 & 0,125 & Bangkrut \\
\hline 2015 & 0,137 & Bangkrut \\
\hline MANDIRI & & \\
\hline 2013 & 0,334 & Bangkrut \\
\hline 2014 & 0,319 & Bangkrut \\
\hline 2015 & 0,318 & Bangkrut \\
\hline
\end{tabular}

Sumber Data Primer yang diolah, 2019

Berdasarkan tabel 2 hasil rekapan nilai S-Score model Springate pada tahun 2013 dari sampel empat perusahaan Bank yaitu PT. Bank Negara Indonesia Tbk, PT. Bank Rakyat Indonesia Tbk, PT. Bank Tabungan Negara Tbk dan PT.Bank Mandiri Tbk diprediksi bangkrut, tahun 2014 dan tahun 2015 juga diprediksi bangkrut. Dengan kondisi tersebut maka keempat BUMN tersebut harus berhati hati dalam mengelola kinerja keuangan.Hal ini dikarenakan, keunggulan dalam berkompetisi tidak hanya dipengaruhi oleh besarnya permodalan suatu bank saja, tetapi banyak faktor yang mempengaruhi. Oleh karena itu, keempat bank BUMN tersebut harus berhatihati dalam menentukan kebijakan bagi perusahaan kedepannya. Dikarenakan jika manajemen salah dalam menentukan keputusan maka akan berakibat buruk yaitu kebangkrutan usaha. Peningkatan kinerja dapat dilakukan dengan cara meningkatkan volume penjualan produk bank pada setiap tahunnya, meningkatkan efisiensi penggunaan sumber daya yang dimiliki oleh perusahaan.

\section{KESIMPULAN}

Hasil analisis model Altman Z-score menunjukkan bahwa bank BUMN yang go public di BEI tahun 2013-2015 diprediksi mengalami kebangkrutan selama tiga tahun berturut-turut dengan titik cut-off bangkrut di bawah 1,20. Hal ini dikarenakan selama tahun 2013-2015, kemampuan perusahaan dalam menghasilkan laba masih kurang maksimal sehingga perusahaan diprediksi mengalami kebangkrutan.

Hasil analisis model Springate S-score menunjukan bahwa keempat bank BUMN yang go publik di BEI tahun 2013-2015 diprediksi mengalami 
kebangkrutan selama tiga tahun berturut -turut dengan nilai S-score $<0,862$ yang masuk dalam prediksi bangkrut, hal ini dikarenakan kemampuan menghasilkan laba kurang maksimal tidak dapat mengikuti kenaikan hutang . Hasil analisis dengan menggunakan dua model yaitu model Altman Z-score dan model Springate ke empat bank BUMN yang go publik di BEI tahun 20132015 diprediksi bangkrut, kedua model tersebut menghasilkan analisis yang tidak berbeda.

\section{Saran}

\section{Bagi Perusahaan Bank BUMN yang Go Public di BEI}

Hasil analisis model Altman Z-score dan model Springate S-score menunjukkan bahwa semua bank BUMN yang go public di BEI diprediksi mengalami kebangkrutan. Oleh karena itu, pihak manajemen perusahaan harus segera melakukan tindakan evaluasi terhadap kondisi keuangan perusahaan. Selain itu, perbaikan kinerja diperlukan setiap bank agar semakin kecil kemungkinan mengalami kebangkrutan.

\section{Bagi Investor}

Dalam melakukan keputusan investasi, sebaiknya investor harus benar-benar selektif. Perusahaan dengan nilai Z-score atau S-score rendah dengan prediksi bangkrut, jika bank tidak melakukan perbaikan kinerja perusahaan sebaiknya dihindari karena potensi kebangkrutan cukup besar.

\section{DAFTAR PUSTAKA}

Arikunto, Suharsimi. 2010. Prosedur Penelitian : Suatu Pendekatan Praktik. Edisi Revisi. Jakarta, Rineksa Cipta.

Darsono dan Ashari. 2005. Pedoman Praktis Memahami Laporan Keuangan. Edisi 1. Yogyakarta, Andi Offset.

Dendawijaya, Lukman. 2009. Manajemen Perbankan. Edisi 2. Bogor, Ghalia Indonesia.

Endang Purwanti, 2016. Analisis Perbedaan Model Altman Z-score Dan Model Springate s-score Dalam Memprediksi Kebangkrutan Perusahaan Pertambangan Di Indonesia,Jurnal STIE SEMARANG Vol.8 Edisi Juni 2016

Gulo, W. 2005. Metodologi Penelitian. Jakarta, PT. Grasindo. 
Hanafi, Mamduh M. dan Abdul Halim. 2005. Analisis Laporan Keuangan. Edisi 2. Yogyakarta, YKPN.

Hanafi, Mamduh M. 2004. Manajemen Keuangan. Cetakan 1. Yogyakarta, BPFE.

Harahap, Sofyan Syafri. 2001. Analisa Kritis Atas Laporan Keuangan. Jakarta. PT. Raja Grafindo Persada.

Hartono, Jogiyanto. 2004. Metodologi Penelitian Bisnis. Edisi 2004-2005. Yogyakarta, BPFE.

Iis Nurhasanah. 2012. Penggunaan Rasio Keuangan Sebagai Prediktor Potensi Financial Distress dan Kebangkrutan Pada Sektor Perbankan Syariah Dengan Model Altman Z-score (Studi Kasus Pada Bank Umum Syariah Periode 2010-2011). Skripsi, Universitas Islam Negeri Sunan Kalijaga, Yogyakarta. (Diakses pada Bulan Juli 2016) [http://www.google.co.id/url?q=http://digilib.uin-suka.ac.id/10047/1/]

Kamal, ST. Ibrah Mustafa. 2012. Analisis Prediksi Kebangkrutan Pada Perusahaan Perbankan Go Public di Bursa Efek Indonesia (Dengan Menggunakan Model Altman Z-score). Skripsi, FEB Universitas Hasanuddin, Makassar. (Diakses pada Bulan Juli 2016) [http://www.google.co.id/url?q=http://repository.unhas.ac.id/]

Kasmir. 2005. Bank dan Lembaga Keuangan Lainnya. Edisi Revisi. Jakarta, PT. RajaGrafindo Persada.

Utama. 2010. Pengantar Manajemen Keuangan. Edisi 1. Jakarta, Kharisma Putra . 2012. Dasar-Dasar Perbankan. Edisi Revisi. Jakarta, PT. RajaGrafindo Persada.

Kosasih. 2010. Analisis Tingkat Kebangkrutan Model Altman dan Foster Pada Perusahaan Textille dan Garment Go Public di Bursa Efek Indonesia (Periode 2007-2009). Skripsi, FEB Universitas Islam Negeri Syarif Hidayatullah, Jakarta. (Diakses pada Bulan Juli 2016) [http://www.google.co.id/url?q=http://repository.uinjkt.ac.id/]

Munawir. 2002. Analisa Laporan Keuangan. Edisi 4. Yogyakarta, Liberty.

Nazir, Moh. 2011. Metode Penelitian. Cetakan 7. Bogor, Ghalia Indonesia. Ni made Evi Dwi Prihanthini,Maria M. Ratna Sari, 2013, Prediksi Kebangkrutan 
Dengan Model Grover,Altman Zscore,Sprinate Dan Zwijewski Pada Perusaahn Food And Beverage Di Bursa Efek Indonesia, Jurnal Akuntansi Iniversitas Udayana

Pujiwati, Titik. 2015. Analisis Kebangkrutan Dengan Metode Z-score Altman dan Zmijewski (Studi Kasus Pada Perusahaan Consumer Goods Industry yang Terdaftar di Bursa Efek Indonesia Periode 2010-2014). Skripsi, Program Studi Strata Satu Akuntansi STIE AMA, Salatiga.

Rahardjo, Mandala Manurung Prathama. 2004. Uang, Perbankan, dan Ekonomi Moneter (Kajian Kontekstual Indonesia). Jakarta, Fakultas Ekonomi Universitas Indonesia.

Rindjin, Ketut. 2000. Pengantar Perbankan dan Lembaga Keuangan Bukan Bank. Jakarta, PT. Gramedia Pustaka Utama.

Simorangkir, O.P. 2000. Pengantar Lembaga Keuangan Bank dan Non Bank. Cetakan Pertama. Jakarta, Ghalia Indonesia.

Sopiyanah. 2015. Analisis Prediksi Kebangkrutan Dengan Model Z-score Altman dan Model Springate Pada Perusahaan Pertambangan di Indonesia (Studi Empiris Pada Perusahaan Pertambangan yang Terdaftar Pada Bursa Efek Indonesia Tahun 2010-2014). Skripsi, Program Studi Strata Satu Akuntansi STIE AMA, Salatiga.

Soeratno, Lincoln Arsyad. 2003. Metodologi Penelitian : Untuk Ekonomi \& . Yogyakarta, UPP AMD YKPN.

Sugiyono. 2012. Memahami Penelitian Kualitatif. Bandung. CV. Alfabeta.

Suhartono, Eko Wahyu. 2015. Analisis Model Altman Z-score Dalam Memprediksi Kebangkrutan (Studi Kasus Pada Perusahaan Farmasi yang Terdaftar di Bursa Efek Indonesia (BEI) Periode 2013-2014). Skripsi, Program Studi Strata Satu Akuntansi STIE AMA, Salatiga.

Sunyoto, Danang. 2013. Analisis Laporan Keuangan untuk Bisnis (Teori dan Kasus). Cetakan Pertama. Jakarta, CAPS (Center of Academic Publishing Service).

Tika, Moh. Pabandu. 2006. Metodologi Riset Bisnis. Jakarta, PT. Bumi Aksara.

Yulianti, Erlita. 2012. Analisis Rasio Keuangan Untuk Memprediksi Kebangkrutan Perusahaan Pada PT. Kimia Farma (Persero) Tbk. Periode 2006-2010. Skripsi, Program Studi Strata Satu Manajemen STIE AMA, Salatiga. 